\title{
NEWS AND VIEWS
}

\section{Yugoslavia}

GERMANY's attempt to fasten a strangle-hold on Yugoslavia by 'diplomatic means' may prove to have been an even greater blunder than the miscalculation of Mussolini's threat to Greece. The Axis powers, like Germany in the War of 1914-18, have shown themselves singularly inept in estimating the force of the spirit of resistance in a free people prepared to endure suffering even to martyrdom in defence of a way of life and a tradition which embody their highest ideals. No doubt the German leaders have been confirmed by their experiences of recent years in a cynical realism which backs mechanized forces against an idealism with little to rely upon beyond the strength of its right arm and the justice of its cause. Yugoslavia, however, stands in a category different from those nations until lately free, which have succumbed to the traitor within their gates. By the bloodless revolution of March 26-27, Yugoslavia, to quote Mr. Churchill, "found her soul". Her three peoples stand united in their resistance to aggression. Nor must it be forgotten that each one of them has a long and honourable tradition in the cause of freedom.

When the German Führer sought to bring Yugoslavia into subjection as Rumania and Bulgaria had been brought into subjection, had he forgotten how the reorganized Serbian army in the War of 1914-18, after three years of exile and eclipse, showed themselves worthy sons of the heroes of the field of Kossovo, how they were the first of the Allied troops to break through the ring of the Central Powers, and how in a drive, which in the difficult conditions of the terrain was little if at all less spectacular than some of the recent advances of British troops in Africa, expelled the enemy from their country within a few weeks? Now Yugoslavia has been forced to take up arms, her army, composed of men who are among the bravest and strongest fighters in the world's armed forces, aided by the difficulties of a country which offers litcle facility for the technique of mechanized warfare, may well prove, as it did in the last War, the pivot upon which will turn the struggle on behalf of freedom. As in the War of 1914-18 the health of the armed forces will need special attention. During 1916-17, malaria claimed a deadly toll. In fact, medical grounds might well prove ultimately as important as strategic (see page 436 of this issue).

The independence of Serbia from Turkey was established by the Treaty of Berlin in 1878. After the revolution in Austria-Hungary, Slovenia, Croatia, Dalmatia and Bosnia declared their independence, and their union with Serbia, together with that of
Montenegro, which had been voted on November 13, 1918, was proclaimed on December 1, 1918, when the official name of the State was announced as being the Triune Kingdom of the Serbs, Croats and Slovenes. Further modifications of boundaries followed, and on October 3, 1929, the name of the State was changed to the Kingdom of Yugoslavia. The estimated population at the beginning of 1936 was nearly fifteen millions. All religions recognized by law enjoy the same rights, and comprise the following : Serbian Orthodox, $48 \cdot 7$ per cent ; Roman Catholic, 37.45 per cent; Greek Catholic, 0.32 per cent; Protestant, $1 \cdot 66$ per cent; Moslem, 11.2 per cent; Jews, 0.49 per cent; others, 0.18 per cent. Primary education is free and compulsory. Secondary, technical and agricultural educational facilities are good. There are three universities, namely, the University of Belgrade with about five thousand students, University of Zagreb with about five thousand students, and the University of Lyublyana, founded in 1920 .

\section{Agricultural Policy in Great Britain}

ON April 3, the House of Commons went into Committee of Supply on a supplementary vote for the Ministry of Agriculture. The Minister (Mr. R. S. Hudson), in his reply to Earl Winterton, pointed out that between 1914 and 1918, before Mr. Lloyd George started his food production campaign, about 32 per cent of the cultivable land of Great Britain was under crops. By the end of 1918 that was raised to 38 per cent. At the beginning of this War, the percentage was only 28 , but in the same period it has been increased to 40 per cent. Thus, in the War of 1914-18, 2,300,000 acres were ploughed up, and it is to be expected that by this spring $3,750,000$ will be ploughed up. Against this, it must be realized that the population of the United Kingdom has risen since 1917 from $41,000,000$ to $47,750,000$, while the land available to provide the food has decreased by $2,500,000$ acres. Thus, the farming community has made a very remarkable contribution to the British war effort. The farming survey is to be revised and will be of great value for the food production cam. paign and even more valuable to the post-war agricultural policy.

The Minister of Agriculture is persuaded that the quickest and biggest increase in production can be obtained by increasing the productivity of the existing arable land, improving the existing grassland, and above all by raising the standard of farming. In the last seven months, the various committees have done very nearly as much towards draining land as it took the Italian Government thirteen 
years to do in reclaiming the Pontine marshes. Many parks, too, have been ploughed up. Golf courses are not so valuable, but where they can make a substantial contribution they will be asked to do so, while those unsuitable for ploughing will be used for grazing sheep.

In regard to research, the Agricultural Research Council is to be granted an increased sum for use at its unfettered discretion for promoting basic or fundamental research (see also p. 434 of this issue of NATURE). Thus it is hoped to use for the advantage of agricultural research the best brains of the scientific world. The Minister proposes to appoint for England and Wales a body which will be directly responsible to him and which will be concerned to devise methods for ensuring that promising results of research are applied as rapidly as possible to the problems of agriculture and incorporated in the everyday practice of the farmer. A similar body is to be appointed for Scotland. The question of the reform of agricultural education is also to be considered.

\section{Science and Democracy}

The American Association for the Advancement of Science recently forwarded to the British Association a resolution adopted by its Council, inviting the collaboration of British men of science with their American colleagues in framing a charter of democracy on scientific principles. The resolution was passed to express whole-hearted support of the rights of free peoples of the world and the desire of scientific men to share in the responsibility of maintaining them at this time of international stress. It was intended as a significant joining of 'hands across the sea' in a common cause and with the hope that the grasp might lead to effective action.

When this expression of unity of feeling and purpose with Great Britain in the present War was communicated to the Council of the British Association, the resolution was referred to the Committee of the Division for the Social and International Relations of Science. It need scarcely be said that the friendly approach from the United States was highly appreciated, and the co-operation suggested was gladly undertaken. The wording of the American resolution invited co-operation "in attempting to formulate, upon scientific principles, an international charter of democracy". It became clear, however, from inquiries that this phrase represented an attitude and a hope, and was not intended to be a precise term of reference for any committee which might be appointed by either of the two Associations to consider the subject. The Committee of the British Association Division therefore decided first to formulate a statement of the democratic fellowship of science, believing that such a charter would include the basic elements of scientific principles of democracy. This charter has been drafted and communicated to the American Association as well as to the Council of the British Association, as a contribution to the co-operative effort of Englishspeaking scientific communities to promote the advancement of knowledge and action in an international spirit. Whether a charter of the scientifio commonwealth can be made the foundation of a world fellowship has yet to be considered.

\section{University of Liverpool: Air Raid Damage}

IN a recent raid on Liverpool some of the University buildings suffered damage. One of the engineering laboratories received a direct hit and was practically wrecked. Part of the Medical School was also severely damaged, but the effect here was less direct and the structure is not seriously im. paired. Other buildings of the University suffered from blast, many windows, roof-lights, and doors being destroyed. There is, however, no reason to fear that the work of the University will be restricted; the remaining engineering laboratories are adequate to carry on the work of the Faculty with little reduction of efficiency, and repairs are proceeding rapidly on the other laboratories. The amount of the damage is estimated to be about $£ 100,000$, so far as it can be ascertained at present. Fortunately, there was only one casualty and that of a minor kind.

\section{Engineers' Achievements under Aerial Bombardment}

THE twenty-first annual general meeting of the British Electrical Development Association was held in London on March 21 under the presidency of Lord Lytton. The meeting was preceded by a luncheon at which the Minister of Transport was the guest of honour. In reply to Colonel Moore-Brabazon, Lord Lytton pointed out that, in the last twelve months, the electrical industry has undergone the severest test in its existence. In spite of air attacks, electricity supply has suffered no prolonged interruption, but fow of the general public have any idea what this has meant. Too many are apt to take it for granted, like all the other machinery of civilized life to which they are accustomed. In the first place, this 'main. tained supply' was due to improvements in the distributing system which were carried out in the years before the War. It would not have been possible at the time of the War of 1914-18. The national pool of the whole industry, the interconnexion of the mains of different supply authorities and the amalgamation of different competing authorities-measures taken during peace-timomade 'maintained supply' possible. But even so, the results achieved during the past year have been due to the individual bravery of the men who operated the supply.

Lord Lytton expressed the hope that the day is not too far distant when we shall again think more in terms of 'development', because, despite the alarums and excursions of war-time days, the electrical industry has an eye-and a very constructive eyeto the future. In so far as anyone can visualize the problems of reconstruction with which we shall be concerned when the War is ended and the means available in solving them, the Association and various sections of the industry have given considerable thought to the many ways in which electricity can 